\title{
Studi Karakteristik Agronomi Bawang Merah (Allium ascalonicum L.) Varietas Agrihorti-1 dan Mentes dengan Bawang Daun Kultivar Lokal Kalimantan (Allium fistulosum L.) Di Dataran Tinggi Jawa Barat
}

\author{
Study of Characteristics Agronomy Shallot (Allium ascalonicum L.) Varieties Agrihorti-1 and Mentes With Kalimantan \\ Local Cultivar Onion Leaf (Allium fistulosum L.) In The Highlands of Western Java
}

\author{
Salsabila Safitri Armei Rihadi*, R. Prasodjo Soedomo, Kuswarini Sulandjari, Rommy Andhika Laksono
}

Program Studi Agroteknologi, Fakultas Pertanian, Universitas Singaperbangsa Karawang

Jl. HS Ronggowaluyo, Teluk Jambe Timur, Kab. Karawang, 41361

Email : slsblsftr@gmail.com

\begin{abstract}
Abstrak
Permintaan bawang merah dan bawang daun terjadi setiap saat, namun produksi cenderung bersifat musiman. Penelitian ini bertujuan untuk memperoleh karakteristik agronomi dari varietas tanaman bawang merah dan bawang daun yang mampu memberikan hasil tertinggi di dataran tinggi Jawa Barat. Penelitian dilaksanakan di screenhouse Balai Penelitian Tanaman Sayuran Desa Cikole, Kecamatan Lembang, Kabupaten Bandung Barat, Provinsi Jawa Barat. Pada bulan September sampai dengan bulan Desember 2020. Metode penelitian yang digunakan pada percobaan ini yaitu menggunakan metode Rancangan Acak Kelompok (RAK) faktor tunggal yang terdiri dari 3 perlakuan, yaitu : A (bawang merah Agrihorti-1), B (bawang merah varietas Mentes), dan C (bawang daun kultivar lokal Kalimantan) dengan 9 ulangan, kemudian jika terdapat perlakuan yang berpengaruh nyata dilakukan analisis lanjut menggunakan LSD 5\%.Hasil penelitian menunjukkan terdapat pengaruh nyata bawang merah varietas Agrihorti-1 terhadap parameter pengamatan jumlah daun, jumlah anakan, jumlah umbi per rumpun, panjang umbi, berat basah umbi per rumpun, berat basah umbi per plot, berat kering umbi per rumpun, berat kering umbi per plot. Dan bawang merah varietas Agrihorti-1 memiliki hasil tertinggi pada semua pengamatan karakter agronomi serta hasil produksi.
\end{abstract}

Kata Kunci : Karakteristik Agronomi; Varietas; Bawang Merah; Bawang Daun

\section{Pendahuluan}

Bawang merah dan bawang daun merupakan salah satu komoditas tanaman hortikultura yang sangat potensial serta memiliki nilai ekonomis yang cukup penting, yang telah sejak lama diusahakan oleh petani secara intensif dan juga banyak dikonsumsi oleh masyarakat, serta memiliki prospek cukup baik untuk pemenuhan konsumen domestik dan untuk permintaan ekspor.

Menurut Badan Pusat Statistika (BPS) (2020), produksi bawang merah di Indonesia pada tahun 2019 sebesar 1.580.247 ton. Sedangkan untuk produktivitas bawang daun di Indonesia sebesar 590.596 ton. Dari data tersebut, kemampuan produksi masih belum mampu memenuhi permintaan pasar. Selain itu, kelangkaan benih bermutu dan harga benih yang mahal menjadi kendala pada peningkatan produksi bawang.

Ketersediaan bibit bawang merah mengalami kesulitan karena keterbatasan varietas lokal yang ada. Saat ini petani bawang merah di Indonesia lebih banyak menggunakan varietas impor karena terdapat beberapa keunggulan daripada varietas lokal (Theresia, V., 2016).

Beberapa jenis bawang merah yang populer di Indonesia salah satunya yaitu bawang merah varietas Agrihorti-1 yang mempunyai keunggulan produksi 20,4 ton/ha, dengan bentuk umbi pipih bulat dan besar. Selain itu, bawang merah varietas Mentes juga mempunyai keunggulan produksi 7,10 sampai dengan 27,58 ton/ha, dengan keunggulan daya tahan simpan lebih lama. namun, bawang merah lebih banyak diusahakan di dataran rendah, karena produksinya lebih efisien dan kondisi agroklimatnya lebih mendukung untuk pertumbuhan tanaman secara optimal (Basuki, 2009). Karena tanaman bawang merah menyukai tempat yang terbuka dengan intensitas sinar matahari penuh.

Selain agroekosistem, untuk mengembangkan tanaman perlu mempertimbangkan penggunaan varietas unggul dari program pemuliaan tanaman. Karena tidak semua varietas dapat adaptif pada daerah pengembangan, ketersediaan varietas yang sesuai dengan lingkungan akan berpotensi hasil tinggi, serta dapat mempengaruhi daya hasil dan adaptasi varietas (Kartinaty et al., 2018).

Adaptasi tanaman terhadap lingkungan merupakan rekayasa sifat-sifat karakteristik anatomi dan fisiologi untuk keberhasilan menyesuaikan kehidupan di habitat tertentu. Respon dari adaptasi pada jangka pendek dapat terlihat pada perubahan morfologi maupun fisiologi dan anatomi dalam jangka yang lama (Haryanti, S., 2009).

Di Indonesia untuk pengembangan bawang merah melalui pemuliaan konvensional dengan mudah dapat dilakukan. Namun, pada bidang pemuliaan tanaman banyak membutuhkan informasi tentang sifat-sifat agronomi, komponen hasil dan hasil, keragaman fenotipik, dan genotipik dari plasma nutfah yang dimiliki, guna peningkatan hasil daya serta ketahanan terhadap penyakit (Mangeldorf (1952); Soedomo (2006)). Oleh karena itu, upaya untuk memenuhi permintaan bawang merah dan bawang daun melalui peningkatan produksi harus terus dilakukan dengan penggunaan program seleksi dan perbaikan varietas akan sangat efektif (Ahmad et al., 2014). 
Seleksi merupakan suatu kegiatan awal yang dilakukan untuk memperbaiki karakter tanaman yang diwariskan pada suatu populasi baru dengan sifat genetik yang baru (Peni et al., 2018). Keunggulan suatu benih atau bibit tanaman pada dasarnya ditentukan oleh faktor genetik (gen) tanaman itu sendiri. Namun, dapat juga di pengaruhi oleh fakor nongenetik (Iingkungan) dan terdapat interaksi diantara keduanya (Fajriah, N., 2018).

Untuk mendapatkan informasi tersebut, dapat melihat pada karakter agronominya yaitu karakter-karakter yang berperan dalam penentuan pada potensi hasil suatu tanaman dengan menilai besarnya keragaman genetik, indentifikasi varietas, menilai jumlah aksesi, dan sebagainya (Putra et al., 2015).

Karakter agronomi berpengaruh besar atau memiliki hubungan yang kuat terhadap kedua komponen daya hasil tersebut dapat dipertimbangkan pada saat seleksi genotipe. Zanetta et al., (2016), pada peningkatan hasil tanaman kedelai dapat diupayakan melalui pemuliaan dengan penggunaan kultivar kedelai lokal, kultivar unggul, dan galur-galur potensial dalam merakit varietas unggul baru. Keragaman karakter tanaman dapat menentukan potensi hasil dan meningkatkan efisiensi penggunaan bahan genetik dalam pemuliaan tanaman untuk meningkatkan produksi.

Gultom, T. et al., (2015), pada hasil penelitian Morfologi Dan Produksi Empat Varietas Bawang Merah (Allium cepa L. Var. Agregatum) Di Dataran Tinggi menyatakan bahwa varietas Peking, Thailand, India, dan Samosir memberikan pengaruh yang sangat nyata terhadap tinggi tanaman, jumlah helaian daun dan jumlah anakan bawang merah serta tidak memberikan pengaruh yang nyata terhadap bobot kering dan bobot basah umbi. Berdasarkan hasil penelitian Sari, V. et al., (2017), tingkat keragaman genetik yang dihasilkan sebesar 27\%. Varietas Bangkok (diameter umbi terbesar) dan genotipe asal Pekanbaru (jumlah siung umbi terbanyak) merupakan genotipe potensial untuk dijadikan varietas unggul bawang merah di Indonesia.

\section{Metode Penelitian}

Penelitian dilaksanakan mulai bulan September 2020 sampai dengan bulan Desember 2020.Berlokasi di rumah kasa Balai Penelitian Tanaman Sayuran Desa Cikole, Kecamatan Lembang, Kabupaten Bandung Barat, Provinsi Jawa Barat.

Bahan yang digunakan dalam penelitian adalah umbi bawang merah varietas Agrihorti-1 dan Mentes, Bibit bawang daun kultivar lokal Kalimantan, Pupuk NPK 16-1616, urea, unsur mikroba, garam, air, kapur dolomit, pupuk kandang ayam, insektisida, fungisida, nutrisi organik, media tanam.

Alat-alat yang digunakan dalam penelitian ini adalah yang digunakan selama penelitian yaitu polybag $30 \times 40 \mathrm{~cm}$, jangka sorong, penggaris, timbangan analitik, gayung, drum, selang, ember, kamera, serta alat tulis.

Metode Penelitian yang digunakan yaitu Rancangan Acak Kelompok (RAK) faktor tunggal. Faktor tersebut terdiri dari 3 perlakuan dengan 9 ulangan, yaitu :

- (A) bawang merah varietas agrihorti-1,

- (B) bawang merah varietas mentes, dan

- (C) bawang daun kultivar lokal Kalimantan.
Parameter yang diamati adalah tinggi tanaman, jumlah anakan, jumlah daun, jumlah umbi per rumpun, panjang umbi, diameter umbi, berat basah umbi per rumpun, berat basah umbi per plot, berat kering umbi per rumpun, berat kering umbi per plot diameter batang, berat basah tanaman per rumpun, berat basah tanaman per plot, warna daun, dan warna umbi.

Data yang sudah diperoleh dianalisis menggunakan analisis sidik ragam. Jika analisis ragam menunjukkan perbedaan yang nyata pada taraf $=5 \%$, maka akan dilanjutkan dengan menggunakan Least Significant Diferent (LSD) pada taraf 5\% (Gomez et al., 1995).

\section{Hasil dan Pembahasan}

\subsection{Tinggi Tanaman}

Berdasarkan hasil sidik ragam menunjukkan adanya berbeda nyata antara varietas bawang merah dan bawang daun terhadap tinggi tanaman pada uji karakteristik morfologi, dapat dilihat pada tabel 1 .

Tabel 1. Rata-rata Tinggi Tanaman

\begin{tabular}{ccc}
\hline Kode & Perlakuan & $\begin{array}{c}\text { Rata-rata Tinggi } \\
\text { Tanaman }(\mathrm{cm})\end{array}$ \\
\hline A & $\begin{array}{c}\text { Bawang merah varietas } \\
\text { Agrihorti-1 }\end{array}$ & $48,21 \mathrm{a}$ \\
B & $\begin{array}{c}\text { Bawang merah varietas } \\
\text { Mentes }\end{array}$ & $43,97 \mathrm{~b}$ \\
C & $\begin{array}{c}\text { Bawang daun kultivar } \\
\text { lokal Kalimantan }\end{array}$ & $50,98 \mathrm{a}$ \\
\hline
\end{tabular}

Ket: Nilai rata-rata pada kolom yang sama diikuti huruf yang sama menunjukkan tidak berberbeda nyata pada uji LSD taraf 5\%.

Rata-rata tinggi tanaman menghasilkan berbeda nyata pada tanaman bawang merah. Pada perlakuan B bawang merah varietas Mentes berbeda nyata dengan perlakuan $\mathrm{C}$ bawang daun kultivar lokal Kalimantan, namun tidak berbeda nyata pada perlakuan A bawang merah varietas Agrihorti-1. Pada perlakuan C bawang daun kultivar lokal Kalimantan menghasilkan rata-rata tinggi tanaman tertinggi sebesar $50,98 \mathrm{~cm}$.

Hal ini menunjukkan bahwa bawang merah dan bawang daun kultivar lokal Kalimantan memiliki daya adaptasi tinggi, yang disebabkan oleh faktor genetik dari tanaman itu sendiri. Sejalan dengan penelitian Ningrum (2011), pada pertumbuhan tanaman mempunyai kemampuan yang berbeda dalam penyesuaian diri atau adaptasi terhadap lingkungannya, pemilihan varietas yang cocok pada suatu daerah sangat diperlukan untuk meningkatkan hasil produksi.

Perbedaan tinggi tanaman disebabkan oleh perbedaan varietas yang digunakan. Tiap varietas dapat mempengaruhi perbedaan keragaman penampilan tanaman yang disebabkan oleh perbedaan sifat genetik, karena terdapatnya gen untuk mengendalikan sifat dari varietas tersebut (Safrida et al., 2019).

\subsection{Umur Berbunga}

Umur berbunga merupakan salah satu karakteristik bawang merah dan bawang daun yang dapat diamati pada saat awalnya muncul bunga pertama, dapat dilihat pada tabel 2 . 
Tabel 2. Rata-rata Umur Berbunga

\begin{tabular}{ccc}
\hline Kode & Perlakuan & $\begin{array}{c}\text { Rata-rata Umur } \\
\text { Berbunga (hari) }\end{array}$ \\
\hline A & $\begin{array}{c}\text { Bawang merah varietas } \\
\text { Agrihorti-1 }\end{array}$ & $7,20 \mathrm{~b}$ \\
B & $\begin{array}{c}\text { Bawang merah varietas } \\
\text { Mentes }\end{array}$ & $8,11 \mathrm{~b}$ \\
C & $\begin{array}{c}\text { Bawang daun kultivar } \\
\text { lokal Kalimantan }\end{array}$ & $93,53 \mathrm{a}$ \\
\hline
\end{tabular}

Ket: Nilai rata-rata pada kolom yang sama diikuti huruf yang sama menunjukkan tidak berberbeda nyata pada uji LSD taraf $5 \%$.

Rata-rata umur berbunga menunjukkan berbeda nyata pada perlakuan tanaman bawang daun kultivar lokal Kalimantan. Pada jumlah umbi perlakuan $\mathrm{C}$ bawang daun kultivar lokal Kalimantan menghasilkan berbeda nyata dengan perlakuan A bawang merah varietas Agrihorti-1, tetapi tidak berbeda nyata perlakuan B bawang merah varietas Mentes.

Pada perlakuan A merupakan tanaman dengan umur berbunga paling pendek yaitu 7,20 hst, lebih pendek dibandingkan dengan tanaman lain serta perlakuan $\mathrm{C}$ merupakan tanaman dengan umur berbunga terlama yaitu 93,53 hst. Perbedaan umur berbunga diduga karena faktor lingkungan.

Umur berbunga dapat ditentukan oleh faktor genetik dan kondisi lingkungan. Selain itu, umur berbunga juga ditentukan oleh interaksi antara lingkungan dan varietas. Menurut Indrianingtyas, I. dan M. Setyo (2020), pada penelitian Studi Karakter Morfologi Dan Kandungan Fenol Pada Sepuluh Genotipe Kedelai (Glycine max (L.) Merrill) terdapatnya perbedaan karakter morfologi yaitu, umur mulai berbunga terpendek adalah benih Malabar 34 hst, untuk umur mulai berbunga terlama yaitu benih Ringgit yang berumur 43 hst dan benih Wilis berumur 45 hst.

Hal ini sejalan dengan penelitian Sjamsijah, N. et al (2018), menyatakan bahwa perbedaan kecepatan umur berbunga disebabkan karena perbedaan genetik dan respon terhadap faktor lingkungan. Dimana pada tanaman kedelai genotipe P2P3 dan P3P2 memiliki umur berbunga lebih pendek dibandingkan genotipe yang lain dan juga lebih pendek dari varietas pembanding malabar dengan rata-rata umur berbunga $37 \mathrm{HST}$, yang dipengaruhi oleh sifat kedua tetuanya P2 dan P3 yang memiliki umur berbunga pendek.

Selain itu, semakin lama umur berbunga, maka fase vegetatif tanaman akan semakin lama sehingga pertumbuhan pada tinggi tanaman kedelai akan semakin tinggi dan jumlah cabang produktif yang terbentuk akan semakin banyak (Sa'diyah, N., et al, 2016).

\subsection{Jumlah Anakan}

Berdasarkan hasil sidik ragam uji LSD pada taraf 5\% menunjukkan adanya berbeda nyata antara varietas bawang merah dan bawang daun terhadap jumlah anakan pada uji karakteristik morfologi, dapat dilihat pada tabel 3.
Tabel 3. Rata-rata Jumlah Anakan

\begin{tabular}{cc|c}
\hline Kode & Perlakuan & $\begin{array}{c}\text { Rata-rata Jumlah } \\
\text { Anakan (batang) }\end{array}$ \\
\hline A & $\begin{array}{c}\text { Bawang merah varietas } \\
\text { Agrihorti-1 }\end{array}$ & $8,31 \mathrm{a}$ \\
B & $\begin{array}{c}\text { Bawang merah varietas } \\
\text { Mentes }\end{array}$ & $7,91 \mathrm{a}$ \\
C & $\begin{array}{c}\text { Bawang daun kultivar } \\
\text { lokal Kalimantan }\end{array}$ & $1,58 \mathrm{~b}$ \\
\hline
\end{tabular}

Ket: Nilai rata-rata pada kolom yang sama diikuti huruf yang sama menunjukkan tidak berberbeda nyata pada uji LSD taraf $5 \%$.

Pada rata-rata jumlah anakan menghasilkan berbeda nyata pada perlakuan tanaman bawang daun kultivar lokal Kalimantan. Pada perlakuan C bawang daun kultivar lokal Kalimantan, berbeda nyata dengan perlakuan A bawang merah varietas Agrihorti-1, namun tidak berbeda nyata dengan perlakuan B bawang merah varietas Mentes. Hasil pengamatan yang diperoleh pada pengamatan jumlah anakan yaitu, perlakuan A bawang merah varietas Agrihorti-1 menghasilkan jumlah anakan terbanyak sebesar 8,31 batang.

Hal ini dapat disebabkan oleh, oleh faktor genetik dan daya adaptasi dari setiap varietas. Pada varietas lokal umumnya tanaman yang kurang responsif terhadap penyerapan hara, jumlah anakan sedikit, berumur panjang dan daya hasil rendah. Sedangkan varietas unggul, tinggi tanamannya rendah sehingga respon terhadap penyerapan hara, jumlah anakan sedang, umur tanaman genjah, toleran terhadap penyakit dan berdaya hasil tinggi (Safrida et al., 2019).

Selain itu, penggunaan pupuk diperlukan dalam pertumbuhan tanaman, seperti penggunaan pupuk organik yang terdapat dalam tanah mampu membuat tanah menjadi subur dan gembur sehingga pertambahan jumlah anakan menjadi lebih cepat meningkat dibandingkan dengan media tanah yang tidak menggunakan bahan organik.

Kurnianingsih et al., (2018), penggunaan media tanam yang dicampurkan dengan pupuk kotoran ayam dapat memberikan tambahan unsur hara bagi tanaman, sehingga didapatkan jumlah anakan tertinggi dibandingkan perlakuan lainnya.

\subsection{Jumlah Daun}

Berdasarkan hasil sidik ragam uji LSD pada taraf 5\% menunjukkan adanya berbeda nyata antara varietas bawang merah dan bawang daun terhadap jumlah daun pada uji karakteristik morfologi, dapat dilihat pada tabel 4. 
Tabel 4. Rata-rata Jumlah Daun

\begin{tabular}{ccc}
\hline Kode & Perlakuan & $\begin{array}{c}\text { Rata-rata Jumlah } \\
\text { Daun (helai) }\end{array}$ \\
\hline A & $\begin{array}{c}\text { Bawang merah varietas } \\
\text { Agrihorti-1 }\end{array}$ & $31,69 \mathrm{a}$ \\
B & $\begin{array}{c}\text { Bawang merah varietas } \\
\text { Mentes }\end{array}$ & $30,33 \mathrm{a}$ \\
C & $\begin{array}{c}\text { Bawang daun kultivar } \\
\text { lokal Kalimantan }\end{array}$ & $9,69 \mathrm{~b}$ \\
\hline
\end{tabular}

Ket : Nilai rata-rata pada kolom yang sama diikuti huruf yang sama menunjukkan tidak berberbeda nyata pada uji LSD taraf 5\%.

Rata-rata jumlah daun menunjukkan berbeda nyata pada perlakuan tanaman bawang daun kultivar lokal Kalimantan. Pada perlakuan C bawang daun kultivar lokal Kalimantan berbeda nyata dengan perlakuan A bawang merah varietas Agrihorti-1, namun tidak berbeda nyata dengan perlakuan B bawang merah varietas Mentes. Hasil pengamatan tertinggi yang diperoleh pada pengamatan jumlah daun yaitu, perlakuan A bawang merah varietas Agrihorti-1 menghasilkan jumlah daun terbanyak sebesar 31,69 helai.

Jumlah daun tanaman merupakan komponen yang dapat menunjukkan pertumbuhan tanaman. Pada pembentukan daun dipengaruhi oleh sifat genetik tanaman, namun lingkungan yang baik dapat mempercepat pembentukkan tersebut (Fatmawaty et al., 2015). Selain itu, Pada bibit umbi yang besar akan menghasilkan daun bawang yang lebih banyak dibanding bibit yang berukuran lebih kecil, dikarenakan bibit berukuran besar akan memberikan pertumbuhan yang baik. Hal ini sesuai dengan pernyataan Nugroho et al., (2017), bahwa perlakuan umbi besar memberikan hasil daun yang lebih banyak, sedangkan pada umbi kecil memberikan hasil daun yang sedikit.

Selain itu, pada perkembangan jumlah daun intensitas cahaya dan suhu akan mempengaruhi perkembangan tanaman serta berperan dalam proses fotosintesis. Semakin banyak daun dapat diartikan semakin banyak cahaya yang dapat ditangkap sehingga proses fotosintesis semakin meningkat. Serta pada kondisi suhu yang tinggi tanaman akan memiliki daun lebih kecil dibandingkan dengan suhu yang rendah tetapi daun menjadi lebih tipis (Rosadi et al., 2019).

\subsection{Jumlah Umbi Per Rumpun}

Berdasarkan hasil sidik ragam uji LSD pada taraf 5\% menunjukkan adanya berbeda nyata antara varietas bawang merah dan bawang daun terhadap jumlah umbi per rumpun pada uji karakteristik morfologi, dapat dilihat pada tabel 5.

Tabel 5. Rata-rata Jumlah Umbi Per Rumpun

\begin{tabular}{ccc}
\hline Kode & Perlakuan & $\begin{array}{c}\text { Rata-rata Jumlah } \\
\text { Umbi Per Rumpun } \\
\text { (umbi) }\end{array}$ \\
\hline A & $\begin{array}{c}\text { Bawang merah varietas } \\
\text { Agrihorti-1 }\end{array}$ & $3,07 \mathrm{a}$ \\
B & $\begin{array}{c}\text { Bawang merah varietas } \\
\text { Mentes }\end{array}$ & $3,06 \mathrm{a}$ \\
C & $\begin{array}{c}\text { Bawang daun kultivar } \\
\text { lokal Kalimantan }\end{array}$ & $0,00 \mathrm{~b}$ \\
\hline
\end{tabular}

Ket: Nilai rata-rata pada kolom yang sama diikuti huruf yang sama menunjukkan tidak berberbeda nyata pada uji LSD taraf $5 \%$.

Rata-rata jumlah umbi per rumpun menunjukkan berbeda nyata pada perlakuan tanaman bawang daun kultivar lokal Kalimantan. Pada jumlah umbi perlakuan $\mathrm{C}$ bawang daun kultivar lokal Kalimantan menghasilkan berbeda nyata dengan perlakuan A bawang merah varietas Agrihorti-1, tetapi tidak berbeda nyata perlakuan B bawang merah varietas Mentes. Hasil pengamatan tertinggi yang diperoleh pada pengamatan jumlah umbi yaitu, perlakuan A bawang merah varietas Agrihorti-1 mendapatkan rata-rata tertinggi sebesar 3,07 umbi.

Menurut penelitian Saidah et al., (2019), jumlah umbi juga disebabkan oleh faktor genetik dan sedikit oleh faktor lingkungan. Seperti, kemampuan tanaman dalam pendistribusian hasil fotosintat mempengaruhi jumlah umbi yang dihasilkan, maka dari itu pemilihan varietas yang digunakan juga menjadi faktornya. Selain itu, Semakin banyak jumlah anakan yang ada maka, semakin banyak jumlah umbi yang dihasilkan. Hal ini sesuai dengan pernyataan Wiguna et al., (2013), baik pada jumlah anakan atau jumlah umbi per tanaman maupun jumlah umbi per plot pada varietas Bima paling tinggi dibanding varietas Maja dan Sumenep. Hal ini disebabkan karena setiap anakan memiliki kemampuan untuk menghasilkan umbi.

Jumlah umbi terbanyak dihasilkan oleh bawang merah varietas Aghrihorti-1. Hal ini sesuai dengan hasil pengamatan pada jumlah anakan bawang merah varietas Agrihorti-1 memiliki jumlah anakan terbanyak.

\subsection{Panjang Umbi}

Berdasarkan hasil sidik ragam uji LSD pada taraf 5\% menunjukkan adanya berbeda nyata antara varietas bawang merah dan bawang daun terhadap jumlah umbi per rumpun pada uji karakteristik morfologi, dapat dilihat pada tabel 6 .

Tabel 6. Rata-rata Panjang Umbi

\begin{tabular}{ccc}
\hline Kode & Perlakuan & $\begin{array}{c}\text { Rata-rata Panjang } \\
\text { Umbi }(\mathrm{cm})\end{array}$ \\
\hline A & $\begin{array}{c}\text { Bawang merah varietas } \\
\text { Agrihorti-1 }\end{array}$ & $2,96 \mathrm{a}$ \\
B & $\begin{array}{c}\text { Bawang merah varietas } \\
\text { Mentes }\end{array}$ & $2,53 \mathrm{~b}$ \\
C & $\begin{array}{c}\text { Bawang daun kultivar } \\
\text { lokal Kalimantan }\end{array}$ & $0,00 \mathrm{c}$ \\
\hline
\end{tabular}

Ket: Nilai rata-rata pada kolom yang sama diikuti huruf yang sama menunjukkan tidak berberbeda nyata pada uji LSD taraf $5 \%$.

Rata-rata panjang umbi menunjukkan sangat berbeda nyata pada perlakuan bawang merah dan bawang daun. Berdasarkan hasil sidik ragam menghasilkan berbeda sangat nyata pada panjang umbi perlakuan A bawang merah varietas Agrihorti-1, dengan perlakuan B bawang merah varietas Mentes, serta berbeda nyata pada perlakuan $\mathrm{C}$ bawang daun kultivar lokal Kalimantan. Hasil pengamatan tertinggi diperoleh pada pengamatan perlakuan A bawang merah varietas Agrihorti-1 menghasilkan rata-rata tertinggi sebesar $2,96 \mathrm{~cm}$. 
Pada pembentukan panjang umbi akan sejalan dengan pertambahan diameter umbi. Faktor genotipe dapat mempengaruhi pembentukan panjang umbi. Menurut neni, N. (2018), pada keragaan produksi pada percobaan pertama setiap variabel pengamatan di lapang dipengaruhi oleh genotipe. Panjang umbi berkaitan dengan umbi yang dihasilkan. Hal ini berkaitan dengan daya adaptasi tanaman terhadap faktor suhu yang menjadi pembatas dalam proses pembesaran umbi kentang.

Selain itu, struktur tanah sangat berpengaruh karena semakin baik struktur tanah maka semakin mudah untuk umbi berkembang. Pada perbaikan struktur tanah dapat menggunaakan pemberian pupuk agar tanah semakin gembur. Hal ini sejalan dengan penelitian Yasir, M., dan Erlinda, A. (2017), bahwa kombinasi pupuk organik TKKS 10 ton/ha dan KCL $100 \mathrm{~kg} / \mathrm{ha}$ menghasilkan panjang umbi sebesar 15,86 cm dibanding kombinasi lainnya.

3.7. Diameter Umbi

Berdasarkan hasil sidik ragam uji LSD pada taraf 5\% menunjukkan adanya berbeda nyata antara varietas bawang merah dan bawang daun terhadap diameter umbi pada uji karakteristik morfologi, dapat dilihat pada tabel 7.

Tabel 7. Rata-rata Diameter Umbi

\begin{tabular}{ccc}
\hline Kode & Perlakuan & $\begin{array}{c}\text { Rata-rata Diameter } \\
\text { Umbi }(\mathrm{cm})\end{array}$ \\
\hline A & $\begin{array}{c}\text { Bawang merah } \\
\text { varietas Agrihorti-1 } \\
\text { Bawang merah } \\
\text { B }\end{array}$ & $2,05 \mathrm{a}$ \\
& $\begin{array}{c}\text { Bawang daun } \\
\text { kultivar lokal } \\
\text { Kalimantan }\end{array}$ & $2,06 \mathrm{a}$ \\
& Kalimas & $0,00 \mathrm{~b}$ \\
\hline
\end{tabular}

Ket: Nilai rata-rata pada kolom yang sama diikuti huruf yang sama menunjukkan tidak berberbeda nyata pada uji LSD taraf 5\%.

Rata-rata diameter umbi menunjukkan berbeda nyata pada perlakuan tanaman bawang daun kultivar lokal Kalimantan. Hasil sidik ragam menghasilkan berbeda nyata pada perlakuan $\mathrm{C}$ bawang daun kultivar lokal Kalimantan, dan tidak berbeda nyata pada perlakuan A bawang merah varietas Agrihorti-1, dan perlakuan B bawang merah varietas Mentes. Hasil pengamatan tertinggi diperoleh pada pengamatan perlakuan B bawang merah varietas Mentes mendapatkan rata-rata tertinggi sebesar $2,06 \mathrm{~cm}$.

Ukuran umbi terdapat 3 macam, yaitu besar, sedang, dan kecil. Bawang merah varietas Mentes menghasilkan diameter umbi paling besar yaitu 2,06. Menurut penelitian C., Azmi et al., (2011), besarnya umbi dipengaruhi oleh faktor genetik. Jika berbagai varietas ditanam di lahan yang sama, maka besar umbi tiap varietas juga berbeda. Hasil besar diameter umbi tidak terlalu dipengaruhi oleh ukuran benih yang digunakan. Pembesaran umbi lapis dapat diakibatkan oleh pembesaran sel yang lebih dominan dari pada pembelahan sel.

Hal ini sejalan dengan penelitian Wiguna et al., (2013), penggunaan benih berukuran sedang atau besar akan memberikan hasil yang sama. Pada penggunaan umbi benih dengan ukuran diameter sedang (14,7-16,7 mm) dapat digunakan oleh petani untuk mengurangi biaya benih berdasarkan ukuran berat. Serta perbedaan varietas menyebabkan perbedaan ukuran umbi yang dihasilkan.

\subsection{Berat Basah Umbi Per Rumpun}

Berdasarkan hasil sidik ragam uji LSD pada taraf 5\% menunjukkan adanya berbeda nyata antara varietas bawang merah dan bawang daun terhadap berat basah umbi per rumpun pada uji karakteristik morfologi, dapat dilihat pada tabel 8 .

Tabel 8. Rata-rata Berat Basah Umbi Per Rumpun

\begin{tabular}{ccc}
\hline Kode & Perlakuan & $\begin{array}{c}\text { Rata-rata Berat Basah } \\
\text { Umbi Per Rumpun (g) }\end{array}$ \\
\hline A & $\begin{array}{c}\text { Bawang merah } \\
\text { varietas Agrihorti-1 } \\
\text { Bawang merah } \\
\text { B }\end{array}$ & $7,64 \mathrm{a}$ \\
C & $\begin{array}{c}\text { Bawietas Mentes } \\
\text { lokal Kalimantan }\end{array}$ & $7,19 \mathrm{a}$ \\
\hline
\end{tabular}

Ket: Nilai rata-rata pada kolom yang sama diikuti huruf yang sama menunjukkan tidak berberbeda nyata pada uji LSD taraf $5 \%$.

Rata-rata berat basah umbi per rumpun menunjukkan berbeda nyata pada perlakuan tanaman bawang daun kultivar lokal Kalimantan. Pada perlakuan $\mathrm{C}$ bawang daun kultivar lokal Kalimantan, berbeda nyata dengan perlakuan A bawang merah varietas Agrihorti-1, dan diikuti perlakuan B bawang merah varietas Mentes. Hasil pengamatan tertinggi yang diperoleh pada pengamatan berat basah umbi per rumpun $\mathrm{t}$ yaitu, perlakuan A bawang merah varietas Agrihorti-1 sebesar 7,64 g.

Bobot basah umbi per rumpun perlakuan A (bawang merah varietas Agrihorti-1) memberikan hasil tertinggi. Bobot basah yang tinggi didapatkan dari pertumbuhan yang optimal, dan dipengaruhi oleh kondisi lingkungan yang ada disekitar tanaman. Selain itu, bobot basah tanaman dipengaruhi oleh kandungan air yang dimiliki pada sel-sel tanaman. Dimana semakin tinggi kandungan air, maka makin tinggi bobot basah yang dihasilkan (Mafula, F., dan Yogi, S., 2019).

Ayu et al., (2016), penyerapan unsur hara dan air yang optimal dapat disebabkan kondisi varietas yang telah beradaptasi dengan lingkungan tumbuhnya. Pertumbuhan dan hasil suatu varietas akan berbeda pada setiap kondisi lingkungan yang berbeda.

\subsection{Berat Basah Umbi Per Plot}

Berdasarkan hasil sidik ragam uji LSD pada taraf 5\% menunjukkan adanya berbeda nyata antara varietas bawang merah dan bawang daun terhadap berat basah umbi per plot pada uji karakteristik morfologi, dapat dilihat pada tabel 9.

Tabel 9. Rata-rata Berat Basah Umbi Per Plot

\begin{tabular}{ccc}
\hline Kode & Perlakuan & $\begin{array}{c}\text { Rata-rata Berat Basah } \\
\text { Umbi Per Plot (g) }\end{array}$ \\
\hline A & $\begin{array}{c}\text { Bawang merah } \\
\text { varietas Agrihorti-1 } \\
\text { Bawang merah }\end{array}$ & $22,87 \mathrm{a}$ \\
B & $\begin{array}{c}\text { varietas Mentes } \\
\text { Bawang daun kultivar } \\
\text { lokal Kalimantan }\end{array}$ & $0,00 \mathrm{c}$ \\
\hline
\end{tabular}

Ket: Nilai rata-rata pada kolom yang sama diikuti huruf yang sama menunjukkan tidak berberbeda nyata pada uji LSD taraf $5 \%$. 
Rata-rata panjang umbi menunjukkan sangat berbeda nyata pada perlakuan bawang merah dan bawang daun. Pada perlakuan $\mathrm{C}$ bawang daun kultivar lokal Kalimantan, berbeda nyata dengan perlakuan A bawang merah varietas Agrihorti1, dan diikuti perlakuan B bawang merah varietas Mentes. Hasil pengamatan tertinggi yang diperoleh pada pengamatan berat basah umbi per plot yaitu, perlakuan A bawang merah varietas Agrihorti-1 sebesar 22,87 g.

Pada bobot basah umbi per plot tertinggi dihasilkan oleh perlakuan A (bawang merah varietas Agrihorti-1) dengan 22,87 gram, perbedaan bobot per rumpun dan bobot per plot dapat disebabkan oleh varietas dan galur yang memiliki potensi hasil berbeda-beda (Silvia, R., 2014). Selain itu, keberhasilan suatu tanaman untuk menghasilkan bobot yang lebih maksimal dapat disebabkan dari genetiknya yang dapat beradapatasi dengan kondisi lingkungan yang ada.

Menurut penelitian Efendi et al., (2020), pada tanaman yang ditanam menggunakan siung berukuran besar menghasilkan hasil panen yang tinggi. Tanaman yang ditanam menggunakan siung berukuran besar menghasilkan bobot umbi yang lebih tinggi sehingga hasil panen meningkat. Karena ketersediaan cadangan makanan dalam jumlah lebih banyak, sehingga menghasilkan bobot umbi bawang putih yang lebih tinggi. Serta semakin tinggi berat basah umbi per rumpun, maka semakin tinggi pula berat basah umbi per plot.

\subsection{Berat Kering Umbi Per Rumpun}

Berdasarkan hasil sidik ragam uji LSD pada taraf 5\% menunjukkan adanya berbeda nyata antara varietas bawang merah dan bawang daun terhadap berat kering umbi per rumpun pada uji karakteristik morfologi, dapat dilihat pada tabel 10

Tabel 10. Rata-rata Berat Kering Umbi Per Rumpun

\begin{tabular}{ccc}
\hline Kode & Perlakuan & $\begin{array}{c}\text { Rata-rata Berat Kering } \\
\text { Umbi Per Rumpun }(\mathrm{g})\end{array}$ \\
\hline A & $\begin{array}{c}\text { Bawang merah } \\
\text { varietas Agrihorti-1 } \\
\text { Bawang merah } \\
\text { B }\end{array}$ & $5,69 \mathrm{a}$ \\
varietas Mentes & $5,39 \mathrm{a}$ \\
B & $\begin{array}{c}\text { kuwang daun } \\
\text { kultivar lokal }\end{array}$ & $0,00 \mathrm{~b}$ \\
\hline
\end{tabular}

Ket: Nilai rata-rata pada kolom yang sama diikuti huruf yang sama menunjukkan tidak berberbeda nyata pada uji LSD taraf $5 \%$.

Rata-rata berat basah umbi per rumpun menunjukkan berbeda nyata pada perlakuan tanaman bawang daun kultivar lokal Kalimantan. Pada perlakuan $\mathrm{C}$ bawang daun kultivar lokal Kalimantan berbeda nyata dengan perlakuan A bawang merah varietas Agrihorti-1, tetapi tidak berbeda nyata dengan perlakuan B bawang merah varietas Mentes. Hasil pengamatan tertinggi yang diperoleh pada pengamatan berat kering umbi per rumpun yaitu, perlakuan A bawang merah varietas Agrihorti-1 sebesar 5,69 g.

Untuk mendapatkan rata-rata berat kering dapat dilakukan penjemuran pada ruang pengering. Suhu merupakan salah satu faktor yang sangat penting dalam suatu proses pengeringan. Pada penggunaan suhu tinggi dapat menyebabkan terjadinya penguapan kandungan air dari dalam umbi sehingga terjadi susut bobot yang meningkat. Saat pengeringan yang umum dilakukan di Indonesia dengan cara tradisional, yaitu disimpan pada ruangan dengan pada suhu $25-30^{\circ} \mathrm{C}$, dan kelembaban relatif $70-80 \%$ yang dapat menghasilkan susut berat sekitar 25\% (Mutia et al., 2014).

Menurut penelitian Ramadhan, A., dan Sumarni, T. (2018), semakin rendah nilai susut bobot umbi, maka semakin baik kualitas umbi tersebut serta daya simpan umbi akan lebih lama. Waktu pengeringan juga akan berpengaruh terhadap penurunan kadar air bahan yang dikeringkan, semakin lama waktu pengeringan maka suhu yang ada di dalam ruang pengering semakin meningkat.

\subsection{Berat Kering Umbi Per Plot}

Berdasarkan hasil sidik ragam uji LSD pada taraf 5\% menunjukkan adanya berbeda nyata antara varietas bawang merah dan bawang daun terhadap berat kering umbi per plot pada uji karakteristik morfologi, dapat dilihat pada tabel 11.

Tabel 11. Rata-rata Berat Kering Umbi Per Plot

\begin{tabular}{ccc}
\hline Kode & Perlakuan & $\begin{array}{c}\text { Rata-rata Berat Kering } \\
\text { Umbi Per Plot }(\mathrm{g})\end{array}$ \\
\hline A & $\begin{array}{c}\text { Bawang merah } \\
\text { varietas Agrihorti-1 } \\
\text { Bawang merah } \\
\text { B }\end{array}$ & $17,36 \mathrm{a}$ \\
& $\begin{array}{c}\text { varietas Mentes } \\
\text { Bawang daun } \\
\text { kultivar lokal } \\
\text { Kalimantan }\end{array}$ & $0,00 \mathrm{bc}$ \\
\hline
\end{tabular}

Ket: Nilai rata-rata pada kolom yang sama diikuti huruf yang sama menunjukkan tidak berberbeda nyata pada uji LSD taraf $5 \%$.

Rata-rata panjang umbi menunjukkan sangat berbeda nyata pada perlakuan bawang merah dan bawang daun. Pada perlakuan C bawang daun kultivar lokal Kalimantan, berbeda nyata dengan perlakuan A bawang merah varietas Agrihorti1 , serta berbeda nyata juga pada perlakuan B bawang merah varietas Mentes. Hasil pengamatan tertinggi yang diperoleh pada pengamatan berat kering umbi per plot yaitu, perlakuan A bawang merah varietas Agrihorti-1 sebesar 17,36 g.

Pada perlakuan A bawang merah varietas Agrihorti-1 merupakan hasil berat kering umbi per plot tertinggi. Hal ini dikarenakan varietas yang sesuai dengan lingkungan setempat dan berpotensi hasil tinggi merupakan faktor yang secara langsung dapat mempengaruhi daya hasil dan adaptasi varietas Menurut Rahman, A. et al., (2016), Hasil dari penelitian macam varietas berpengaruh nyata terhadap berat kering umbi bawang merah umur 45 hst. Penggunaan varietas bawang merah yang berbeda ternyata menghasilkan berat basah umbi dan berat kering umbi yang berbeda, serta akan mempengaruhi laju tumbuh tanaman (LTT) dan produksi bawang merah.

Menurut Sitompul (1995), produksi tanaman biasanya lebih akurat dinyatakan dengan ukuran berat kering dari pada berat basah, karena berat basah sangat dipengaruhi oleh kelembapan. 


\subsection{Diameter Batang}

Berdasarkan hasil sidik ragam uji LSD pada taraf 5\% menunjukkan adanya berbeda nyata antara varietas bawang merah dan bawang daun terhadap diameter batang pada uji karakteristik morfologi, dapat dilihat pada tabel 12 .

Tabel 12. Rata-rata Diameter Batang

\begin{tabular}{ccc}
\hline Kode & Perlakuan & $\begin{array}{c}\text { Rata-rata Diameter } \\
\text { Batang }(\mathrm{cm})\end{array}$ \\
\hline A & $\begin{array}{c}\text { Bawang merah varietas } \\
\text { Agrihorti-1 }\end{array}$ & $0,00 \mathrm{~b}$ \\
B & $\begin{array}{c}\text { Bawang merah varietas } \\
\text { Mentes }\end{array}$ & $0,00 \mathrm{~b}$ \\
C & $\begin{array}{c}\text { Bawang daun kultivar } \\
\text { lokal Kalimantan }\end{array}$ & $1,23 \mathrm{a}$ \\
\hline
\end{tabular}

Ket: Nilai rata-rata pada kolom yang sama diikuti huruf yang sama menunjukkan tidak berberbeda nyata pada uji LSD taraf $5 \%$.

Rata-rata diameter batang menunjukkan berbeda nyata pada perlakuan tanaman bawang daun kultivar lokal Kalimantan. Berdasarkan hasil sidik ragam menunjukkan berbeda nyata perlakuan $\mathrm{C}$ bawang daun kultivar lokal Kalimantan, dan tidak berbeda nyata pada perlakuan A bawang merah varietas Agrihorti-1, dan diikuti perlakuan B bawang merah varietas Mentes. Hasil pengamatan tertinggi yang diperoleh pada pengamatan diameter batang bawang daun yaitu, perlakuan $\mathrm{C}$ bawang daun kultivar lokal Kalimantan menghasilkan rata-rata tertinggi sebesar $1,23 \mathrm{~cm}$.

Dimana diameter batang yang dihasilkan dapat memiliki hasil yang berbeda-beda sesuai dengan faktor gen yang mendominasi pertumbuhan tanaman (Silvia, R., 2014). Pada tanaman, batang merupakan daerah akumulasi pertumbuhan tanaman khususnya pada tanaman yang lebih muda sehingga dengan adanya unsur hara yang dapat mendorong pertumbuhan vegetatif tanaman. Menurut penelitian Satria et al., (2015), penggunaan unsur hara seperti unsur $\mathrm{N}$ dapat mendorong pertumbuhan vegetatif tanaman seperti, sintesa protein, pembentukan sel-sel baru, serta pembentukan klorofil pada daun. Pembetukan klorofil akan memacu laju fotosintesis dan akan memberikan pertambahan pada ukuran lingkar batang.

\subsection{Berat Basah Tanaman Per Rumpun}

Berdasarkan hasil sidik ragam uji LSD pada taraf 5\% menunjukkan adanya berbeda nyata antara varietas bawang merah dan bawang daun terhadap berat basah per rumpun pada uji karakteristik morfologi, dapat dilihat pada tabel 13. Tabel 13. Rata-rata Berat Basah Tanaman Per Rumpun

\begin{tabular}{ccc}
\hline Kode & Perlakuan & $\begin{array}{c}\text { Rata-rata Berat Basah } \\
\text { Tanaman Per Rumpun } \\
(\mathrm{g})\end{array}$ \\
\hline A & $\begin{array}{c}\text { Bawang merah } \\
\text { varietas Agrihorti-1 } \\
\text { Bawang merah } \\
\text { varietas Mentes } \\
\text { B }\end{array}$ & $0,00 \mathrm{~b}$ \\
C & $\begin{array}{c}\text { kultivang daun lokal } \\
\text { Kalimantan }\end{array}$ & $0,00 \mathrm{~b}$ \\
\hline
\end{tabular}

Ket: Nilai rata-rata pada kolom yang sama diikuti huruf yang sama menunjukkan tidak berberbeda nyata pada uji LSD taraf 5\%.
Rata-rata berat basah tanaman per rumpun menunjukkan berbeda nyata pada perlakuan tanaman bawang daun kultivar lokal Kalimantan. Pada perlakuan $\mathrm{C}$ bawang daun kultivar lokal Kalimantan, berbeda nyata dengan perlakuan A bawang merah varietas Agrihorti-1, dan diikuti perlakuan B bawang merah varietas Mentes. Hasil pengamatan tertinggi yang diperoleh pada pengamatan diameter batang bawang daun yaitu, perlakuan $\mathrm{C}$ bawang daun kultivar lokal Kalimantan sebesar 6,78 g.

Bawang daun kultivar lokal Kalimantan beradaptasi dengan baik pada dataran tinggi. Selain itu, Menurut Susantidiana (2011), unsur hara merupakan salah satu faktor yang menunjang pertumbuhan dan produksi tanaman. Unsur hara harus tersedia dalam jumlah yang cukup sehingga pertumbuhan dan produksi akan optimal.

Karena bawang daun termasuk dalam sayuran yang dikonsumsi daunnya, maka memerlukan unsur hara tambahan yang lebih banyak agar dapat membantu dalam pertumbuhan dan perkembangan tanaman terutama untuk daunnya. Menurut Manullang et al., (2019), Selain unsur hara makro pada tanaman bawang daun dapat ditambahkan penggunaan unsur hara mikro atau penggunaan pupuk daun. Karena pada penggunaan pupuk daun dapat meningkatkan hasil produksi.

\subsection{Berat Basah Tanaman Per Plot}

Berdasarkan hasil sidik ragam uji LSD pada taraf 5\% menunjukkan adanya berbeda nyata antara varietas bawang merah dan bawang daun terhadap berat basah per plot pada uji karakteristik morfologi, dapat dilihat pada tabel 14

Tabel 14. Rata-rata Berat Basah Tanaman Per Plot

\begin{tabular}{ccc}
\hline Kode & Perlakuan & $\begin{array}{c}\text { Rata-rata Berat Basah } \\
\text { Tanaman Per Plot }(\mathrm{g})\end{array}$ \\
\hline A & $\begin{array}{c}\text { Bawang merah } \\
\text { varietas Agrihorti-1 } \\
\text { Bawang merah } \\
\text { B }\end{array}$ & $0,00 \mathrm{~b}$ \\
C & $\begin{array}{c}\text { Bawaietas Mentes } \\
\text { lokal Kalimantan }\end{array}$ & $0,00 \mathrm{~b}$ \\
\hline
\end{tabular}

Ket: Nilai rata-rata pada kolom yang sama diikuti huruf yang sama menunjukkan tidak berberbeda nyata pada uji LSD taraf 5\%.

Rata-rata berat basah per plot menunjukkan berbeda nyata pada perlakuan tanaman bawang daun kultivar lokal Kalimantan. Pada perlakuan $\mathrm{C}$ bawang daun kultivar lokal Kalimantan, berbeda nyata dengan perlakuan A bawang merah varietas Agrihorti-1, dan diikuti perlakuan B bawang merah varietas Mentes. Hasil pengamatan tertinggi yang diperoleh pada pengamatan diameter batang bawang daun tanaman yaitu, perlakuan $\mathrm{C}$ bawang daun kultivar lokal Kalimantan sebesar 17,08 g.

Berat basah per plot pada tanaman bawang daun dihasilkan sebesar 17,08 gram. Berat basah merupakan berat tanaman pada saat tanaman masih hidup dan sebelum tanaman layu akibat kekurangan air. Menurut Novizan (2005), berat basah tanaman sangat dipengaruhi oleh banyaknya air yang diserap oleh tanaman melalui akar. Berat basah selain ditentukan oleh banyaknya daun sebagai tempat untuk fotosintesis, juga dipengaruhi oleh ketersedian unsur hara yang berperan dalam mendukung pertumbuhan tanaman. 
Menurut hasil penelitian Misfahak, dan Zuchrotus, S., (2014), pada penimbunan hasil fotosintesis dan kadar air yang lebih banyak dapat menyebabkan hasil berat basah tanaman menjadi lebih tinggi. Selain itu, banyaknya jumlah daun juga dapat meningkatkan hasil berat basah pada tanaman, karena daun sebagai organ yang berfungsi untuk fotosintesis.

\subsection{Warna Daun}

Warna daun merupakan salah satu karakteristik bawang merah dan bawang daun yang dapat diamati dengan meggunakan colour chart. Warna pada daun bawang merah dan bawang daun berbeda-beda pada tiap varietasnya, dapat dilihat pada tabel 15 .

Tabel 15. Warna Daun

\begin{tabular}{ccc}
\hline Kode & Perlakuan & Warna Daun \\
\hline A & Bawang merah varietas & Moderate Olive \\
& Agrihorti-1 & Green \\
B & Bawang merah varietas & Greyish Olive \\
& Mentes & Green \\
C & Bawang daun kultivar & Dark Yellowish \\
& lokal Kalimantan & Green \\
\hline
\end{tabular}

Berdasarkan hasil dari pengamatan warna daun didapatkan bawang merah varietas Agrihorti-1 dengan warna Moderate Olive Green (hijau agak tua), bawang merah varietas Mentes dengan warna Greyish Olive Green (hijau tua keabu-abuan), dan bawang daun kultivar lokal Kalimantan dengan warna Dark Yellowish Green (hijau tua agak kekuningan). Warna pada daun dapat dipengaruhi banyak atau sedikitnya klorofil pada daun. Klorofil adalah pigmen pemberi warna hijau pada tumbuhan, alga dan bakteri fotosintetik. Kandungan klorofil pada daun dipengaruhi oleh faktor lingkungan yaitu intensitas cahaya, suhu dan kelembaban udara (Zakiyah et al., 2018).

Pada suhu yang tinggi berpengaruh terhadap menurunnya stabilitas warna. Dimana terjadi dekomposisi dan perubahan struktur pigmen yang menyebabkan pemucatan pada warna. Intensitas cahaya yang terlalu rendah akan menghasilkan produk fotosintesis yang tidak maksimal, sedangkan intensitas cahaya yang terlalu tinggi akan berpengaruh terhadap aktivitas sel-sel stomata daun sehingga mengakibatkan terhambatnya pertumbuhan tanaman (Kurniyati et al., 2010).

3.16. Warna Umbi

Warna umbi merupakan salah satu karakteristik bawang merah yang mudah diamati dengan cara kasat mata, namun juga dapat meggunakan colour chart. Pada tiap varietas bawang merah baik warna kulit umbi ataupun warna daging umbi terdapat perbedaan warna, dapat dilihat pada tabel 16 .

Tabel 16. Warna Kulit Umbi Bawang Merah

\begin{tabular}{ccc}
\hline Kode & Perlakuan & $\begin{array}{c}\text { Warna Kulit Umbi } \\
\text { Bawang Merah }\end{array}$ \\
\hline A & Bawang merah & Strong Reddish \\
varietas Agrihorti-1 & Purple \\
B & Bawang merah & varietas Mentes \\
C & Bawang daun kultivar & Deep Red \\
& lokal Kalimantan & - \\
\hline
\end{tabular}

Tabel 17. Warna Daging Umbi Bawang Merah

\begin{tabular}{ccc}
\hline Kode & Perlakuan & $\begin{array}{c}\text { Warna Daging } \\
\text { Umbi Bawang } \\
\text { Merah }\end{array}$ \\
\hline A & Bawang merah varietas & $\begin{array}{c}\text { Dark Purplish } \\
\text { Agrihorti-1 }\end{array}$ \\
B & Bawang merah varietas & $\begin{array}{c}\text { Greysh Purplish } \\
\text { Mentes }\end{array}$ \\
C & Bawang daun kultivar & Red \\
lokal Kalimantan & - \\
\hline
\end{tabular}

Berdasarkan hasil dari pengamatan warna kulit umbi didapatkan bawang merah varietas Agrihorti-1 dengan warna Strong Reddish Purple (merah tua keunguan), bawang merah varietas Mentes dengan warna Deep Red (merah tua). Serta untuk warna daging umbi menggunakan color chart didapatkan bawang merah varietas Agrihorti-1 dengan warna Dark Purplish Red (merah keunguan tua), bawang merah varietas Mentes dengan warna Greyish Purplish Red (merah keungu-unguan). Perbedaan pada warna kulit dan daing umbi selain dipengaruhi oleh kondisi lingkungan dan adaptasi tanaman. Warna pada umbi bawang dipengaruhi oleh kandungan pigmen. Tanaman memiliki pigmen alami seperti klorofil, kartenoid, tannin dan antosianin. Pada bagian umbi bawang merah mengandung pigmen yaitu senyawa antosianin dan flavonoida (Fatma, C., A., 2020).

Menurut Marco et al., (2011), antosianin merupakan komponen bioaktif kelompok flavonoid yang dapat memberikan warna merah, biru, ungu pada bagian bunga, daun, umbi, buah, dan sayur. Pada sifat perubahan warna dipengaruhi oleh $\mathrm{pH}$ dan struktur dari antosianin. Semakin pekat atau kuat warna yang dihasilkan pada tanaman menunjukkan bahwa semakin besar pula konsentrasi antosianin yang terdapat pada tanaman tersebut (Priska, 2018).

\section{Kesimpulan}

Hasil penelitian dapat disimpulkan bahwa Perlakuan A Bawang merah varietas Agrihorti-1 memberikan hasil tertinggi pada parameter pengamatan jumlah anakan, jumlah daun, jumlah umbi per rumpun, panjang umbi, diameter umbi, berat basah per rumpun, berat basah per plot, berat kering umbi per rumpun, dan berat kering umbi per plot. Pada Perlakuan $\mathrm{C}$ bawang daun kultivar lokal Kalimantan memberikan hasil tertinggi pada parameter pengamatan tinggi tanaman, umur berbunga, diameter batang, berat basah per rumpun, dan berat basah per plot.

\section{Ucapan Terima Kasih}

Ucapan terima kasih disampaikan kepada Bapak Drs. R. Prasoedjo Soedomo, APU, Ibu Dr. Kuswarini Sulandjari, Ir., MP. dan Bapak Rommy Andhika Laksono, S.P., M.P., selaku pembimbing. Serta semua pihak yang ikut membantu atas dedikasi dan kerjasama selama penelitian berlangsung. 


\section{Daftar Pustaka}

Ahmad, M., S., L., Aji, H., W., dan Soeranto, H. 2014. Identifikasi Pengaruh Beberapa Karakter Agronomi Terhadap Daya Hasil Sorgum (Sorghum bicolor L. Moench) Dengan Analisis Lintas. Jurnal Ilmiah Aplikasi Isotop dan Radiasi. 10 (2).

Ayu, N., G., Abdul, R., dan Sakksa, S. 2016. Pertumbuhan Dan Hasil Dua Varietas Bawang Merah (Allium ascalonicum L.) Pada Berbagai Jarak Tanam. e-J. Agrotekbis. 4 (5): 530-536.

Azmi, C., I.M. Hidayat., dan G. Wiguna. 2011. Pengaruh Varietas Dan Ukuran Terhadap Produktivitas Bawang Merah. Jurnal Hortikultura. 21(3):206- 213

Badan Pusat Statistik. 2020. Statistik Pertanian. Kementrian Pertanian.

Basuki, R.S. 2009. Analisis kelayakan teknis dan ekonomis teknologi budidaya bawang merah dengan benih biji botani dan benih umbi tradisional. J. Hort. 19 (3): 5-8

Fajriah, N. 2018. Karakter Agronomi Kedelai (Glycine max (L.) Merrill) Hasil Induksi Mutasi Dengan Sodium Azida Pada Tanah Salin. Skripsi. Universitas Diponegoro.

Fatma, C., A. 2020. Sintesis Zat Warna Alami dari Kulit Bawang Merah (Allium ascalonium L) Dengan Metode Ekstraksi Ultrasonik dengan Mordan Jeruk Nipis (Citrus Aurantifolia). Skripsi. Universitas Muhammadiyah Surakarta

Fatmawaty, A., A., S., dan Ritawati, L.N. Said. 2015. Pengaruh Pemotongan Umbi dan Pemberian Beberapa Dosis Pupuk NPK Majemuk Terhadap Pertumbuhan dan Hasil Tanaman Bawang Merah (Allium ascolanicum L.). J. Agrologia. 4 (2): 69-77.

Gultom, T., Endang, S., dan Rolan, S. 2015. Morfologi dan Produksi Empat Varietas Bawang Merah (Allium cepa L. Agregatum Group) Di Dataran Tinggi. [Skripsi]. Universitas Negeri Medan.

Gomez, K.A. dan A.A.Gomez. 1995. Statistical procedures for agricultural research (Prosedur statistik untuk penelitian pertanian, alih bahasa E. Syamsuddin, J.S. Baharsyah, dan A.H. Nasution). UI Press. Jakarta.

Indrianingtyas, I., dan M. Setyo, P. 2020. Studi Karakter Morfologi Dan Kandungan Fenol Pada Sepuluh Genotipe Kedelai (Glycine max (L.) Merrill). Berkala Ilmiah Pertanian. 3 (1) :1-6.

Kartinaty, T., Hartono, dan Serom. 2018. Penampilan Pertumbuhan Dan Produksi Lima Varietas Bawang Merah (Allium ascalonicum) Di Kalimantan Barat. Buana Sains. 18 (2): 103 - 108.

Kurnianingsih, A., Susilawati, dan Marlin, S. 2018. Karakter Pertumbuhan Tanaman Bawang Merah Pada Berbagai Komposisi Media Tanam. J. Hort. 9(3): 167-173

Kurniaty R., Budiman B., dan Surtani M. 2010. Pengaruh Media dan Naungan Terhadap Mutu Bibit Suren (Toona sureni MERR.). Jurnal Penelitian Hutan Tanaman. 7 (2) : 77-83.

Mafula, F. dan Yogi, S. 2019. Pengaruh Sistem Olah Tanah Terhadap Pertumbuhan Dan Hasil Beberapa Varietas Bawang Merah (Allium ascalonicum L.). J. Produksi Tanaman. 7 (3) : 457 - 463.

Marco PH, Poppi RJ, Scarminio IS, Tauler R. 2011. Investigation of the $\mathrm{pH}$ effect and UV radiation on kinetic degradation of anthocyanin mixtures extracted from Hibiscus acetosella. Food Chem. 125:1020 1027.

Misfahak, dan Zuchrotus S. 2014. Pertumbuhan Tanaman Bawang Putih (Allium sativum L.) Dengan Pemberian Air Kelapa (Cocos nucifera L.) Sebagai Sumber Belajar Biologi SMA Kelas XII. Jupemasi-Pbio. $1(1): 16-21$

Mutia, A., K., Purwanto, Y., A., dan Pujantoro, L. 2014. Perubahan Kualitas Bawang Merah (Allium ascalonicum L.) Selama Penyimpanan Pada
Tingkat Kadar Air Dan Suhu Yang Berbeda. J. Pascapanen. 11 (2): $108-115$.

Neni, N., Awang, M., dan Muhammad, S. 2018. Keragaan Produksi Kentang G2 Genotipe IPB Asal Stek dan Umbi di Garut Jawa Barat. Bul. Agrohorti. 6 (3) : $397-404$

Ningrum, A., N., P. 2011. Penampilan Dan Asosiasi Sifat Agronom Sembilan Genotipe Kedelai Pada Musim Kemarau II 2010 Di Jember. Skripsi. Universitas Jember.

Nugroho, U., Rahmat, A., dan Netty, E. 2017. Uji Efektivitas Ukuran Umbi dan Penambahan Biourine Terhadap Pertumbuhan Dan Hasil Bibit Bawang Merah (Allium ascalonicum L.). J. Agriprima. 1 (2): 118-125.

Novizan. 2005. Petunjuk Pemupukan Yang Efektif. Agromedia Pustaka Jakarta.

Peni, Rina, Agus, M., dan Mayasari, Y. 2018. Karakter Agronomi Kapas (Gossypium hirsutum) Var. Kanesia 10 Di Kota Palopo. Prosiding Seminar Nasional. 4 (1)

Putra, A., Maimun, B., dan Nyimas, S. 2015. Penampilan Karakter Agronomi Beberapa Genotipe Harapan Tanaman Kedelai (Glycine $\max$ [L.] Merill) Generasi $\mathrm{F}_{6}$ Hasil Persilangan Wilis X Mlg 2521 . J. Agrotek Tropika. 3 (3): 348-354

Priska, M., Natalia, P., Ludovicus, C., dan Yulius, D., N. 2018. Review: Antosianin Dan Pemanfaatannya. Cakra Kimia. 6 (2).

Rahman, A., Jamzuri, H., dan Chatimatum, N. 2016. Kajian Pertumbuhan Dan Hasil Tiga Varietas Bawang Merah Pada Berbagai Kepadatan Populasi Yang Ditanam Di Lahan Kering Marginal Kecamatan Sungai Raya Kabupaten Hulu Sungai Selatan. Zira’ah. 43 (3) : 332 340.

Ramadhan, A., F., N., dan Titin, S. 2018. Respon Tanaman Bawang Merah (Allium ascalonicium L.) Terhadap Pupuk Kandang Dan Pupuk Anorganik (NPK). J. Produksi Tanaman. 6 (5): 815-822.

Rosadi, A., P., Winarto, R., dan Bahidin, L., M. 2019. Pengaruh Ketinggian Tempat Terhadap Pertumbuhan Tanaman Bawang Merah (Allium ascalonium L) Di Luwuk. Babasal Agrocyc Journal. 1 (1): 21-26.

Sa'diyah, N., Christian, R., S., dan Maimun, B. 2016. Korelasi dan Analisis Lintas Karakter Agronomi Kedelai (Glycine max [L.] Merrill) Keturunan Persilangan Wilis X MLG 2521. Jurnal Penelitian Pertanian Terapan. 16 (1): 45-53.

Safrida, Nana., A., dan Yusrizal. 2019. Respon Beberapa Varietas Padi Lokal (Oryza sativa L.) Terhadap Amelioran Abu Janjang Sawit Pada Lahan Gambut. Jurnal Agrotek Lestari. 5 (1): 28-38.

Saidah, Muchtar, Syafruddin, dan Retno, P. 2019. Pertumbuhan Dan Hasil Panen Dua Varietas Tanaman Bawang Merah Asal Biji Di Kabupaten Sigi, Sulawesi Tengah. Pros. Semnas Masy Biodiv. Indonesia. 5 (2).

Satria, N., Wardati, dan M. Amrul., K. 2015. Pengaruh Pemberian Kompos Tandan Kosong Kelapa Sawit Dan Pupuk NPK Terhadap Pertumbuhan Bibit Tanaman Gaharu (Aquilaria malaccencis). JOM Faperta. $2(1)$

Sari, V., Miftahudin, dan Sobir. 2017. Keragaman Genetik Bawang Merah (Allium cepa L.) Berdasarkan Marka Morfologi dan ISSR. J. Agron. Indonesia. 45(2):175-18

Silvia, R., 2018. Uji Pertumbuhan Dan Produksi Beberapa Genotipe Tanaman Tomat (Lycopersicum esculentum Mill.) Di Dataran Rendah. Skripsi. Universitas Riau.

Sitompul, S, M. dan B, Guritno. 1995. Analisis Pertumbuhan Tanaman UGM. Press. Yogyakarta.

Sjamsijah, N., Novi, V., dan Suwardi. 2018. Uji Daya Hasil Beberapa Genotipe Tanaman Kedelai (Glycine max (L.) Merrill) Produksi 
Tinggi dan Umur Genjah Generasi F6. Agriprima. 2 (2) : 106 116.

Soedomo, R., P. 2006. Seleksi Induk Tanaman Bawang Merah. J. Hort. 16(4):269-282.

Theresia, V., Anna, F., dan Netti, T. 2016. Analisis Persepsi Petani Terhadap Penggunaan Benih Bawang Merah Lokal Dan Impor Di Kabupaten Cirebon, Jawa Barat. J. Penyuluhan. 12 (1).

Wiguna, G,. Hidayat,. I., M., dan Azmi, C. 2013. Perbaikan Teknologi Produksi Benih Bawang Merah Melalui Pengaturan Pemupukan, Densitas, Dan Varietas. J. Hort. 23 (2): 137-142.

Yasir, M., dan Erlinda, S. 2017. Pengaruh Pupuk Organik dan Pupuk KCl Terhadap Pertumbuhan Dan Hasil Ubi Jalar Ungu (Ipomoea batatas Poir). JOM FAPERTA. 4 (2).

Zanetta, C., U., Agung, K., dan Budi, W. 2016. Karakteristik Agronomi Dan Fisik Biji Sebagai Penduga Keragaman Serta Penciri Spesifik Genotipe Pada Kultivar Unggul dan Galur Harapan Kedelai. Prosiding Seminar Hasil Penelitian Tanaman Aneka Kacang dan Umbi.

Zakiyah, M., Togar, F., M., dan Reine, S., W. 2018. Kandungan Klorofil Daun Pada Empat Jenis Pohon Di Arboretum Sylva Indonesia Pc. Universitas Tanjungpura. J. Hutan Lestari. 6 (1): 48-55. 